GEOLOGY OF POWESHIEK COUNTY $\mid$ :

BY

S. W. STOOKEY 


\title{
GEOLOGY OF POWESHIEK COUNTY
}

\author{
BY S. W. STOOKEY
}

\section{CONTENTS}

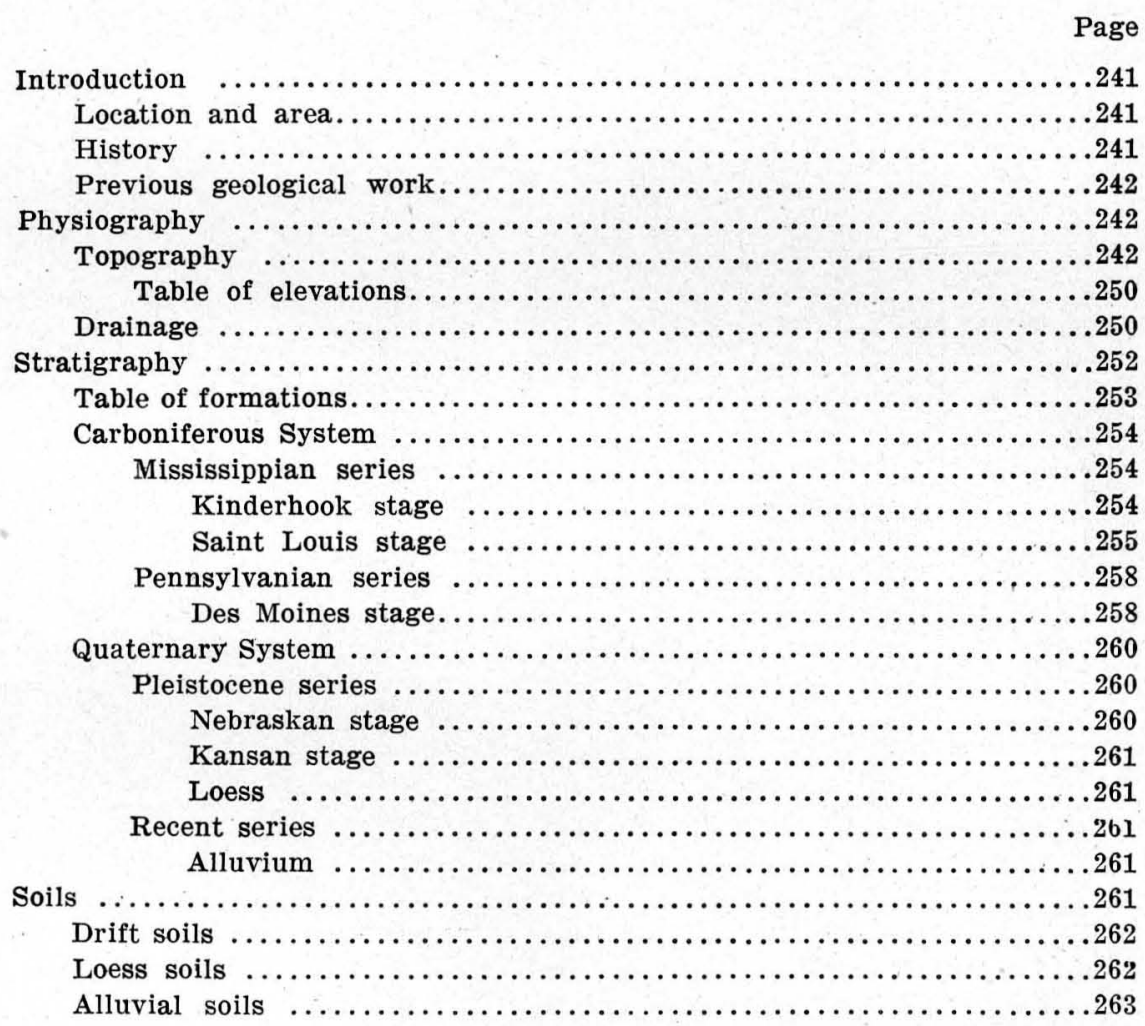




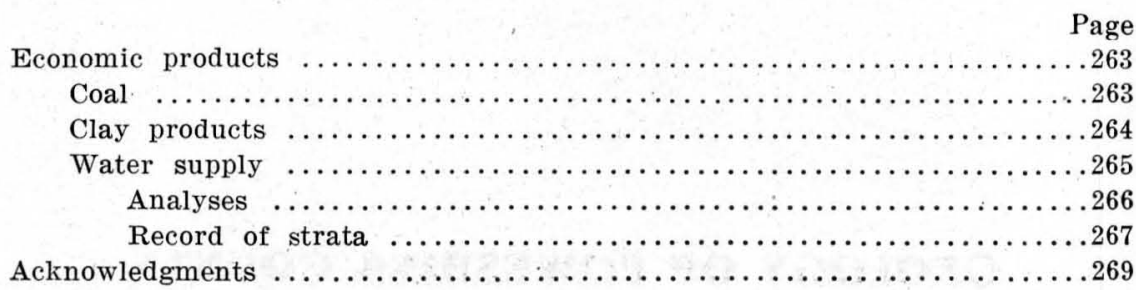




\section{GEOLOGY OF POWESHIEK COUNTY \\ . INTRODUCTION}

LOCATION AND AREA.

Poweshiek county lies southeast of the center of the State of Iowa. It is in the fourth tier from the south and is the fourth county west from the Mississippi river. To the north lies Tama county, to the east Iowa, Mahaska and Keokuk border it on the south, and Jasper forms its west boundary. From the center of the area to the Mississippi river is about one hundred miles, and Des Moines is fifty miles to the west. It is included in the area described by McGee in his Pleistocene History of Northeastern Iowa. The name is that of a famous Fox or Musquakee chief, this county having formed part of the territory occupied by that tribe of the aborigines before the white man took possession.

The area under consideration embraces townships 78 to 81 north, and ranges 13 to 16 west of the 5th principal meridian. It contains sixteen congressional townships and 576 square miles, or 369,360 acres.

HISTORY.

The first settlement of Poweshiek county was made in 1843 by Richard B. Ogden, followed next year by D. Satchel and Richard Cheesman. In 1848 the county was organized, the first county commissioners being Jacob Yeager, Martin Snyder and Richard B. Ogden. In 1854 colonists from the eastern states under the leadership of the Rev. J. B. Grinnell of New York, after careful investigation of various localities, selected as a most suitable place for settlement the tract of land embraced in township 80, range 16 west, in this county. The city of Grinnell and Iowa College are the historic results, and this selection out of the splendid domain of government lands then open 
to settlement, speaks in eloquent terms of the beauty of landscape, the richness of soil, the abundant water supply and the general healthfulness and desirability that have always characterized this highly favored spot.

PREVIOUS GEOLOGICAL WORK.

The report of James Hall, 1858, makes some reference to Poweshiek county. Attention is called to the lack of exposures of the indurated rocks except along the North Skunk river; to the Subcarboniferous limestones probably extending from Tama and Marshall counties through Poweshiek; to the rock quarry at Walker's Mill on the North Skunk river.

McGee in his Pleistocene History of Northeastern Iowa makes a number of references to this county. He refers to its topography, to the predominance of sandstones in the Coal Measure strata, to a deformation of the strata southwest of Grinnell, and to the asymmetric character of the stream valleys.

Under the present survey Keyes has treated at some length the subject of the coal of the county, ${ }^{*}$ Beyer and Williamst the clay industries, and Norton $\ddagger$ the Grinnell Artesian Well Number 1. The lack of rock exposures has of course made it a comparatively uninteresting field for the geologist and accounts for the, small amount of work done and the paucity of its literature.

\section{PHYSIOGRAPHY}

\section{Topography}

The present topographic features of Poweshiek county are expressed in an original plain gently sloping to the east and south. Into this original plain the streams have cut their valleys and a mature drainage system has been established. Remnants of the original plain are still to be seen in the comparatively level divides between the larger streams.

Almost the entire surface of the county is covered with a thick mantle of drift, the Kansan drift sheet, everywhere present except in a few places in the southwestern part of the county

*Iowa Geological Survey, Vol. II, pp. 300-304. 1893.

+Iowa Geological Survey, Vol. XIV, p. 477. 1903.

‡Iowa Geological Survey, Vol. VI, pp. 287-292. 1896. 
where stream action has laid bàre the underlying indurated rocks. Over a considerable part of the county the drift is covered by a veneer of loess. The larger stream valleys are partially filled with alluvium which likewise obscures the glacial drift. Generally throughout the county the roadways expose the yellow or brown bowlder clay of the Kansan till, and in many fields the plow finds evidences of the same material forming the basis of the surface soil.

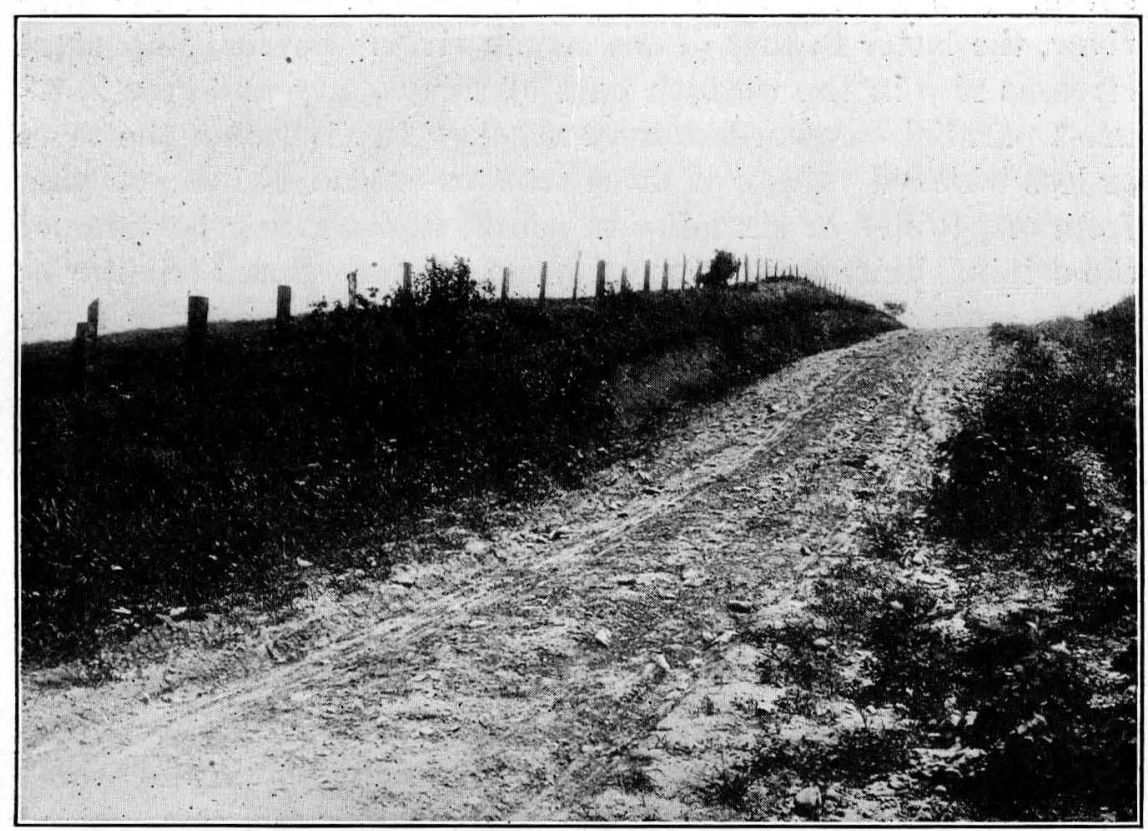

Figure 23. Road showing weathered Kansan drift without loess. Along the north line of section 6, Grinnell township. Typical of many stretches of road in Poweshiek county.

The Kansan glacier in its final retreat evidently left this region a relatively level plain. As the mighty ice-cap made its way down from the north over the country, it doubtless completely changed the features of the ante-Pleistocene surface. The streamways and valleys of that old eroded land surface must have been filled and its ridges and rocky ledges more or less completely overwhelmed and destroyed by the repeated advances and retreats of the ice sheet. Over the whole region was spread to a depth reaching in many places several hundred feet 
the heterogeneous material of the Kansan drift and when the ice sheet finally retreated it left a comparatively level surface. In this drift surface the present topographic features are very largely expressed, and they have been produced largely by the ordinary work of water erosion.

As indicated by the direction of the streams, the slope of the northern and eastern two-thirds of the surface of the county is almost east, while the southwestern third is a little east of south. The former belongs to the drainage system of the Iowa river, the latter to that of the Skunk river. Several important streams rise in the western part of this county and flow in almost parallel eastward courses through it. Between the more or less widened valleys of these streams extend divides, varying from one to five or six miles in width, representing portions of the original drift plain of the Kansan glacier. Small tributaries of the main streams head back in these divides, breaking up in dendritic fashion into very complex systems of ravines and gullies. Gradually under the operation of the erosive agencies these initial gullies are working their way farther and farther back into the divides, enlarging the area of the valleys and diminishing the area of the uninvaded upland.

Throughout the county there is the almost endless repetition of this type of topography. East and west roads that skirt these uplands present a succession of hill and dale, that is exceedingly trying to the traveller. Now the road runs over the crest of a ridge which is a spur of the upland plain, on the top of which will be found a capping of the drab, pebbleless, fine-grained loess. The next hill may not rise so high, showing no trace of loess, the brown, weathered bowlder clay of the Kansan till forming the roadbed. A series of successively lower hills will be passed over by the road, and finally a transversely running streamlet will be reached. Traced by the eye in one direction the valley of the streamlet will be seen to widen as it advances toward the major eastwardly flowing stream; in the other direction it may be seen to divide and subdivide into innumerable minor valleys that run back into the upland plain. The slopes of the hills are rounded, and the ravines are $V$-shaped. It is a region well advanced toward maturity of drainage and topography. 
One may indeed select his road in such a way as to traverse the county largely on the divides, and thus avoid in large measure the irregularities just mentioned. Such a road is the one running from Grinnell in a southeastward direction to the middle line of the county, thence eastward on the south line of Malcom, Bear Creek and Warren townships to the border of the county. Another upland road is that from Montezuma to Deep

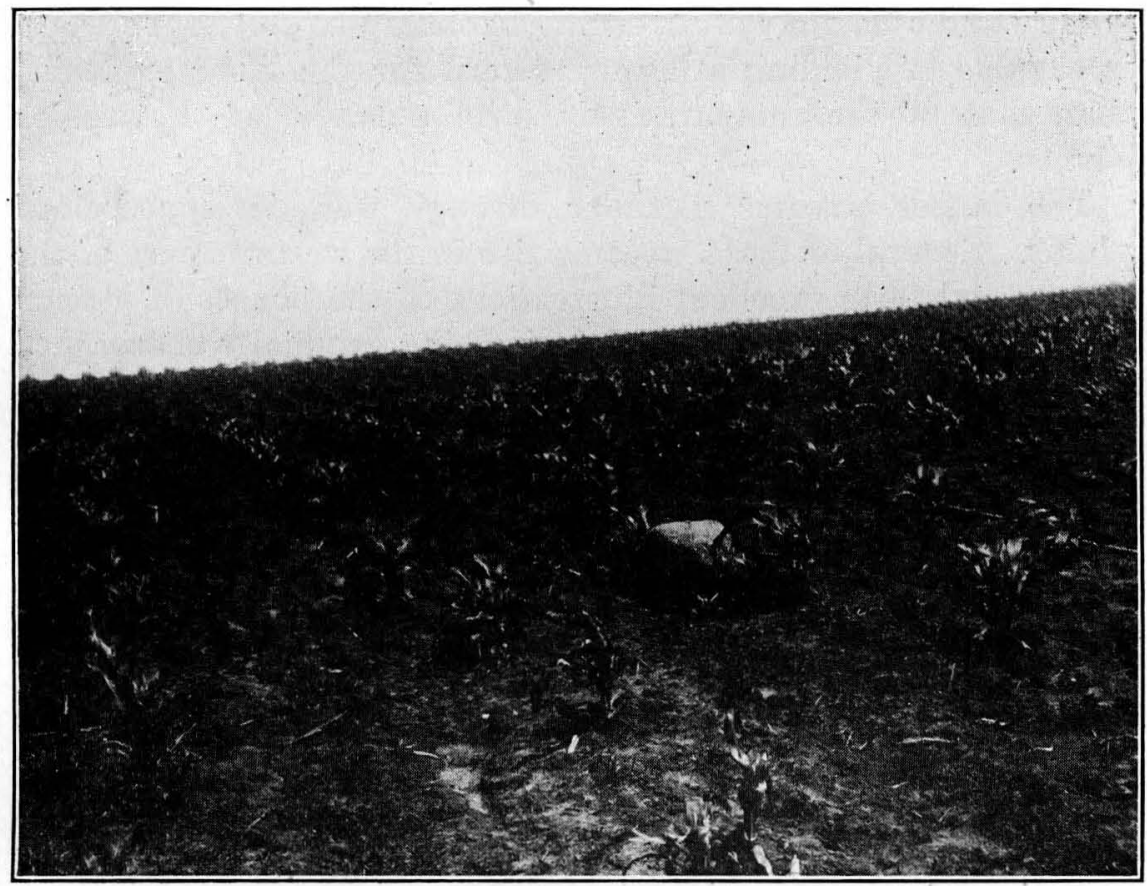

Figure 24. Loessless area in northwest quarter of section 6, Grinnell township.

River; another one mile southeastwardly from Ewart, thence east to the county line. The Iowa Central railroad, which enters the county in Chester township northwest of Grinnell, has selected a route along inter-stream divides for one of its branches, that through Jacobs, Ewart and Montezuma. From the car window the traveller over this line may easily believe that he is passing over a portion of the characteristically level Iowan drift plain instead of the usually hilly Kansan. 
These level areas formed the typical treeless savannas or prairies of the days before the settler transformed the country with plow, grove and homestead. They form today the most ideal farms. The wealth of humus accumulated during the long period when countless annual growths of vegetable matter were returned to the soil is not washed and carried away by rain and stream as is the case in the more hilly parts of the county. Here, the labor of the agriculturist is carried on with a minimum of energy and a maximum of result. Probably no soil in the world is capable of yielding a larger reward for the labor expended than that of the comparatively level uplands of Poweshiek county.

The larger streams meander through well developed flood plains. Several of these streams rise in the western part of the county and form excellent illustrations of the phases of stream development. The Grinnell plain is being gradually encroached upon by gullies and ravines which, uniting to form ever enlarging runs, finally become Little Bear creek and North English river. These streams are thus gradually working back into the divide and lengthening their courses, while their valleys ever widen and encroach upon the inter-stream divides.

The abundant wash from the plains and the materials eroded from the gullies and ravines of the stream heads, as well as that from the valley slopes farther down, have been spread over progressively widening flood plains. As these plains expand the streams increase their meanders. This may be well seen along the Chicago and Northwestern railroad which runs across the east tier of townships in this county, and has located its stations, Carnforth, Guernsey and Deep River at the crossings of Bear creek, North English river and Deep river, respectively. At these stations good views are obtained of these stream valleys where they are best developed. The Chicago, Rock Island and Pacific railroad has utilized as a roadbed the flood plain of Bear creek and Little Bear creek through the western part of Iowa county and through Poweshiek almost to Grinnell.

There is a gentle slope of the northeastern two-thirds of the county toward the east as indicated by the courses of the streams. According to the elevation of points on the upland plain near the western and the eastern borders of the county, 
as Grinnell on the west and Hartwick on the east, the average gradient is not more than two and a half to three feet to the mile. Measured along the stream valleys, however, the fall is much greater, showing the progressive downcutting of these streams into the plain. The average fall of Little Bear creek from Malcom, near the center of the county, to Carnforth, near the eastern border, is eight feet per mile; while from the Grinnell pli:in in which this stream heads, to Malcom, a distance of less than ten miles, the fall is $\mathbf{1 1 9}$ feet. At the crossing of the Northwestern and Rock Island railroads on the flood plain of Bear creek, in Warren township, the stream bed is 150 feet below the upland plain at Hartwick four miles north.

The work of North English river in excavating and widening its valley is nearly as great as that of Bear creek. Jacobs is a station on the Iowa Central railroad in the west central part of the county, situated on the upland plain, and near the heads of North English river. Its elevation according to the profiles of the Iowa Central railway is 971 feet. Guernsey, situated on the flood plain of that river two miles from the east border of the county, is 137 feet lower.

A similar comparison may be made for Deep river in the case of Montezuma, a point five miles from the south border of the county and exactly in the midline from east to west, and Deep River, a point on the flood plain of the stream of the same name, and situated seven miles due east of Montezuma. The elevation of the upland plain at Montezuma is 948 feet and the flood plain at Deep River 862 feet, a difference of eightỳ-six feet.

The southwestern third of the county presents some topographic contrasts, and many similarities to the area already described. The line of separation is determined by the divide between the Iowa river drainage basin, to which most of the county belongs, and that of the Skunk river. As already noted the Iowa Central railroad has utilized this comparatively level remnant of the original Kansan plain for its road bed. The highest points in the county are along the crest of this divide. At Gilman in Marshall county, one mile from the county line, the elevation is 1,090 feet; other points along this crest are: 
Grinnell, 1,011 feet; Jacobs, 971 feet; Ewart, 963 feet; Montezuma, 948 feet; Barnes City, 910 feet. An average slope toward the southeast along this divide of about four feet to the mile is indicated by these figures.

The region to the southwest of this divide belongs to the basin of the North Skunk river. It includes all of Sugar Creek and Union townships, the larger part of Washington and portions of Pleasant and Jackson. Over this area very little of the original Kansan plain remains. The whole presents a thoroughly dissected plain. The slope is toward the southeast, and toward the master stream of the area, the North Skunk river, which crosses the southwest corner of the county, cutting off the southwest third of Sugar Creek township. Here and there on the crests of hills the capping of loess indicates a remnant of the original plain, but almost everywhere the roadways show the brown, weathered, oxidized bowlder clay of the Kansan till at the surface. An exception to this is seen in the bluffs along the North Skunk river, where the loess may generally be found of considerable thickness.

A feature of the stream valleys throughout the county, which has been noted by various geologists as characteristic of the streams of the Kansan drift area in Iowa, is their lack of symmetry. McGee refers to the streams of Poweshiek and Iowa counties as typical examples of these asymmetrical valleys. His comparison of the area of these eastwardly flowing streams to a series of tilted plains with the northern margin raised and the surface gently sloping to the south, to meet the northern raised edge of the next plain, which in turn slopes southward, and so on throughout the area, fairly describes the appearance presented. The stream bed in such a case is along the base of the scarp of the supposed tilted plain. 'The slope of the valley to the south of the stream is short and comparatively steep. The tributaries from the south are few in number and insignificant in size. Looking up this southern slope from the flood plain or stream bed one gets the impression of irregular bluffs of varying height. In the opposite direction the slope is gradual and more or less regular to the crest of the divide. The tributaries from the north are more frequent and of considerable size, draining as they do the comparatively large area of the extended northern 
slope. Admirable illustrations of this peculiarity are found in all the larger streams of the county. In the case of Bear creek in its course throughout Bear Creek township to its junction with Little Bear creek there is not a tributary from the south, while at least four flow in from the north.

The supposition of a series of tilted plains elongated in an east and west direction, as suggested by McGee, might be admissible in an area whose surface topography is determined by indurated rock strata. Faulting or folding of such strata might easily produce an effect of this sort. But in a region such as this whose topographic features are expressed in the drift and are almost exclusively the result of erosive agencies, such an explanation seems scarcely tenable.

Professor Calvin suggests an explanation based upon the principles of erosion and stream action. "This surface in the region under discussion was drained by a number of parallel streams, each flowing toward the east. As soon as these streams cut channels of any considerable depth, the two sides of each channel were differently affected by the agents of erosion. The northward facing surfaces suffered less than the opposite side of the channel from the alternations of freezing and thawing, and consequently the effects of erosion in early winter and spring. They were less affected by the droughts of summer, which tended to check the growth of vegetation and render the surface more pulverulent and more easily attacked by the dashing rain storms. The result was that as the channel was deepened the north side of the valley receded more rapidly than the south, the slopes soon became gradual, the small lateral streams on the north cut back into the highlands with greater facility and greater speed, robbing the secondary streams developed on the south side of the drainage area to the north; and so as a result of normal causes each drainage basin became unsymmetrical, and was converted into a sloping plain with the main drainage streams along its southern margin."

*Geology of Johnson County, Vol. VII, Ann. Rep. Iowa Geol. Survey. 
TABLE OF ELEVATIONS.

Taken from Gannett's Dictionary of Altitudes, 4th Edition, 1906.

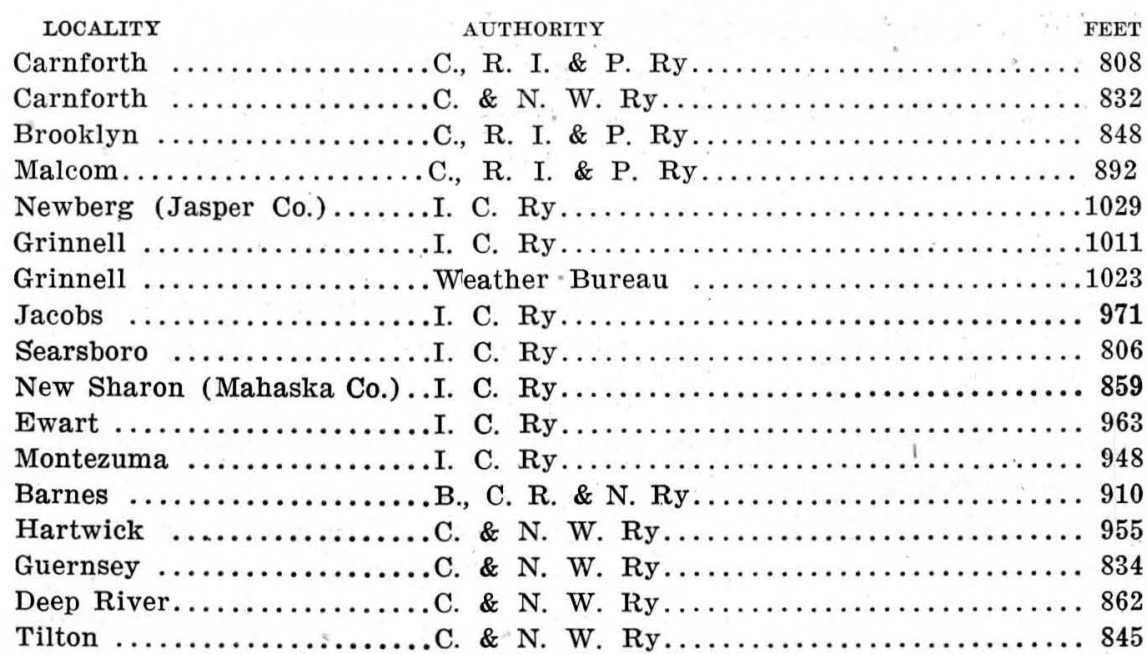

\section{Drainage}

As already indicated in the foregoing discussion Poweshiek county forms a part of two drainage basins, viz., that of the Iowa river and that of the Skunk river. The northern and eastern two-thirds of the county belong to the Iowa river system, and the southwestern third to the Skunk. The whole county presents an area of nearly mature drainage, but no large river flows through it. The North Skunk flowing across the southwest corner, is the largest, but its total length within the county is not great, the linear distance from the points of its entrance and its exit being not more than five or six miles.

No less than six important tributaries of the Iowa river head in the divide that separates the Iowa basin from that of the Skunk. These flow in an easterly course. Walnut creek flows through the northern tier of townships and drains the eastern part of Chester township and approximately the northern twothirds of Sheridan, Madison and Jefferson. It follows the law of these streams in having its longer and more numerous tributaries from the north, and having the southern slope of its valley comparatively short and steep. Several of the tributaries of Bear creek, the next stream to the south, approach to within a 
mile of the stream channel of the Walnut. It leaves the county in section 1, Jefferson township, near the northeast corner of the county.

Bear creek is one of the most important streams of the county. It heads in the divide just beyond the northwest border of the county, and flows entirely through it, draining a considerable part of the two northern tiers of townships. Through Malcom, Bear Creek and Warren townships, its channel is from seventyfive to $\mathbf{1 5 0}$ feet below the upland divide to the north and south. It flows through a widened valley and through the greater part of its course meanders through a flood plain of from one-half mile to a mile in width. It receives no tributaries of consequence from the south (except the eastwardly flowing Little Bear creek) but several from the north, the largest of which is Rock creek.

Little Bear creek heads in Grinnell township, flows through Malcom and Bear Creek townships and joins Bear creek near the center of Warren township. The Chicago, Rock Island and Pacific railway has advantageously utilized its comparatively level valley for a road bed, as it has that of Bear creek eastward to Marengo in Iowa county.

North English river heads in the region south of Grinnell, flows southeast across the northeast corner of Washington township, thence east through Pleasant, Scott and Lincoln townships. With the exception of Bear creek it has a longer course within the county than any other stream. Its flood plain is well developed, especially in the eastern half of its course within the county, and it flows through Scott and Lincoln townships in a valley from fifty to 100 feet lower than the upland plain.

Deep river rises in the southeastern part of Pleasant township, and flows through the southern part of Scott, thence across the northern part of Deep River.

South English river with its tributaries drains the larger part of Jackson and Deep River townships.

The drainage basin of the Skunk river includes the western part of Grinnell township, the southwestern three-quarters of Washington, the southwestern third of Pleasant, the western - third of Jackson, and all of Sugar Creek and Union. Sugar 
creek, West creek, Buck creek and Moon creek, with their numerous secondary and tertiary branches, have cut up this part of the country into a labyrinth of hills and ridges, so that it is the roughest part of the county, and the most thoroughly drained.

\section{STRATIGRAPHY}

In Iowa the oldest Paleozoic rocks outcrop along the streams in the extreme northeastern part of the state; those of successively younger age forming a series of terranes running in a northwest-southeast direction across the state. There is a gentle dip of these successive rock systems toward the southwest, so that in general each formation as it meets the eastern margin of the next younger dips beneath it and continues to be found in deep well sections throughout the state to the southwest. In this way the Cambrian, the Ordovician, the Silurian, the Devonian and the Carboniferous systems of rocks form a series of terranes of varying width over which one passes in succession as he travels across the state from the northeast to the southwest.

The rocks that appear at the surface in Poweshiek county all belong to two groups, widely separated in geologic time, the Pleistocene and the Carboniferous, the former lying unconformably upon the latter. Almost the entire area is covered by a mantle of loose uncemented material of considerable variety, representing chiefly Pleistocene deposits and these are spread over the indurated rock to a depth varying from nothing to three hundred feet or more.

The indurated rocks appear at the surface at only a few points along the North Skunk river, which has excavated more deeply than any other stream in the county, and here has reached the sandstones, shales, coal and lime rock of Carboniferous age. At every other point the hard rocks are buried deeply beneath the mantle of drift, loess and alluvium. Even here the part of the Paleozoic section exposed is comparatively insignificant considered from the standpoint of thickness and length of geologic time represented. Knowledge of the indurated rocks in other parts of the county is matter of inference from the study of borings that have been made for wells or in the search for coal, and from the general relations of the geological formations in 
regions adjacent to this county. The following table exhibits the major groups of the geological record and their subdivisions that are represented in Poweshiek county:

TABLE OF FORMATIONS.

\begin{tabular}{|c|c|c|c|c|}
\hline GROUP & SYSTEM & SERIES & STAGE & FORMATION \\
\hline \multirow[b]{3}{*}{ Cenozoic } & \multirow[b]{3}{*}{ Quaternary } & Recent & & $\begin{array}{l}\text { Alluvium } \\
\text { Humus } \\
\text { Sands, silts, etc. }\end{array}$ \\
\hline & & & Iowan & Loess \\
\hline & & Pleistocene & Kansan & Drift \\
\hline \multirow{4}{*}{ Paleozoic } & \multirow{4}{*}{ Carboniferous } & Pennsylvanian & Des Moines & $\begin{array}{l}\text { Shales } \\
\text { Sandstone } \\
\text { Coal }\end{array}$ \\
\hline & & \multirow[b]{3}{*}{ Mississippian } & & Pella beds \\
\hline & & & Saint Louis & Verdi beds \\
\hline & & & Kinderhook & $\begin{array}{l}\text { Shale } \\
\text { Limestone }\end{array}$ \\
\hline
\end{tabular}

Deep wells sunk through these strata show their thickness, depth and general relations. Three such wells have been sunk at Grinnell. The studies of Professor Norton give interesting and important results bearing upon the geological section in this region.* The following table summarizes his results:

\begin{tabular}{|c|c|c|c|}
\hline FORMATION & THICKNESS & DEPTH & $\begin{array}{l}\text { ELEVATION } \\
\text { ABOVE TIDE }\end{array}$ \\
\hline Pleistocene $\ldots \ldots \ldots \ldots \ldots \ldots \ldots \ldots$ & 212 & 212 & 618 \\
\hline Mississippian and Kinderhook*...... & 358 & 570 & 458 \\
\hline 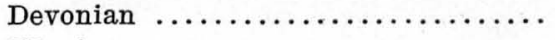 & 370 & 940 & 88 \\
\hline Silurian $\ldots \ldots \ldots \ldots \ldots \ldots \ldots \ldots \ldots \ldots$ & 260 & 1,200 & -172 \\
\hline Maquoketa $\ldots \ldots \ldots \ldots \ldots \ldots \ldots \ldots . \ldots \ldots$ & 120 & 1,320 & -292 \\
\hline Galena-Trenton* $\quad \therefore \ldots \ldots \ldots \ldots \ldots$ & 380 & 1,700 & -672 \\
\hline Saint Peter.$\ldots \ldots \ldots \ldots \ldots \ldots \ldots$ & 40 & 1,740 & -712 \\
\hline Upper Oneota $(?) * \ldots \ldots \ldots \ldots \ldots$ & 262 & 2,002 & -974 \\
\hline New Richmond (?) at............. & $\ldots$ & 2,002 & $\ldots \ldots$ \\
\hline
\end{tabular}

*In place of the terms indicated by the asterisk the following are used in more recent publications of the Iowa Geological Survey: The Kinderhook is included in the Mississippian; for Galena-Trenton Galena-Platteville is substituted; for Upper Oneota Shakopee, and for Lower Magnesian the geographic name Prairie du Chien is used.

A comparison of these results of Professor Norton's study with the record of well number 3 at Grinnell shows the general. similarity in thickness and depth of the formations as follows: 
FORMATION

Pleistocene

THICKNESS

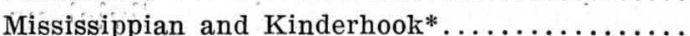

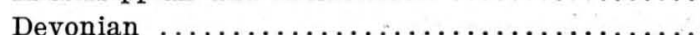

Silurian $\ldots \ldots \ldots \ldots \ldots \ldots \ldots \ldots \ldots \ldots \ldots \ldots$

*Iowa Geol. Surv., “Artesian Wells of Iowa," Vol. VI, pp. 291.

\section{CARBONIFEROUS SYSTEM Mississippian Series KINDERHOOK STAGE.}

No rocks of this stage appear at the surface in Poweshiek county. All that area where they form the country rock is covered to a depth of from two hundred to four hundred feet with glacial deposits, through which the streams have nowhere cut. All that is positively known of rocks of this age in this county is obtained from the meager records of wells that have been sunk here and there into the rocks.

The Grinnell wells show a body of limestone and shale more than 350 feet in thickness next below the drift that is regarded as chiefly representing this stage. Wells in the vicinity of Brooklyn penetrate similar deposits. In the northwest quarter of section 12, Bear Creek township, the Talbott and Thompson well shows the following as reported by W. W. Shannon of Brooklyn :

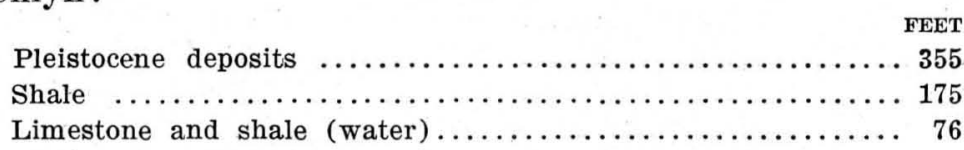

In section 16, Bear Creek township, on the Newkirk farm the well is reported as follows:

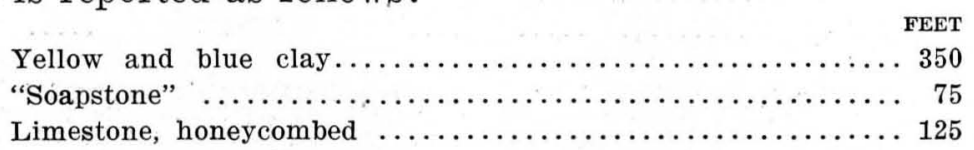

The nearest surface exposure of Kinderhook rocks to the east is at Amana in Iowa county, near the Iowa river. Along the same river in Marshall and Tama counties to the north exposures are found that have been described in detail in the reports by Beyer and Savage. It is not possible to map ac- 
curately the limits of this terrane in Poweshiek county, but it is safe to say that the area to the north and east of the divide between the Iowa river basin and that of the North Skunk has as its country rock the Kinderhook deposits.

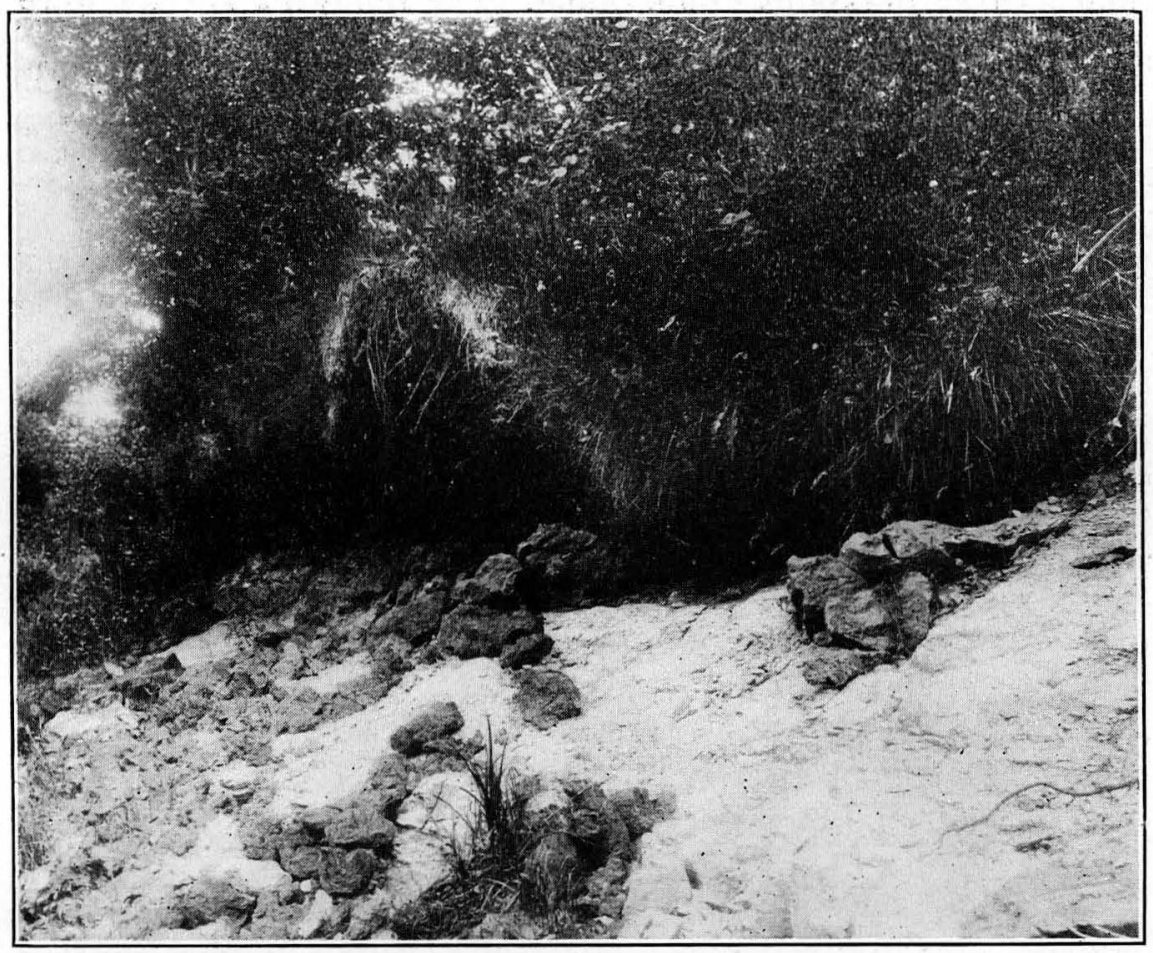

Figure 25. Exposure of Pella beds, Saint Louis limestone, in the south bank of the Skunk river, section 35, Sugar Creek township. The darker, loose masses belong to the overlying Des Moines stage of the Upper Carboniferous or Pennsylvanian series.

SAINT LOUIS STAGE.

Rocks of the Saint Louis stage are exposed at several points along the North Skunk river in the southwest portion of the county. In the southeast quarter of the northwest quarter of section 35, Sugar Creek township, the river has exposed a section as follows:

6. Drift.

5. Sandstone, shaly, partly exposed.

4. Taius.

3. Sandstone, ferruginous, shaly, 6 inches.

2. Limestone and marl, fossiliferous, 7 feet.

1. Limestone at water's edge and bed of stream, compact, fossiliferous. 
Numbers 1 and 2 represent the upper part of the Saint Louis, known as the Pella beds. Numbers 3 and 5 are Des Moines. The contact between the Des Moines and the underlying Pella beds is well seen. Both the lime rock at the water's edge and the marls carry the Saint Louis fauna. The following species were noted:

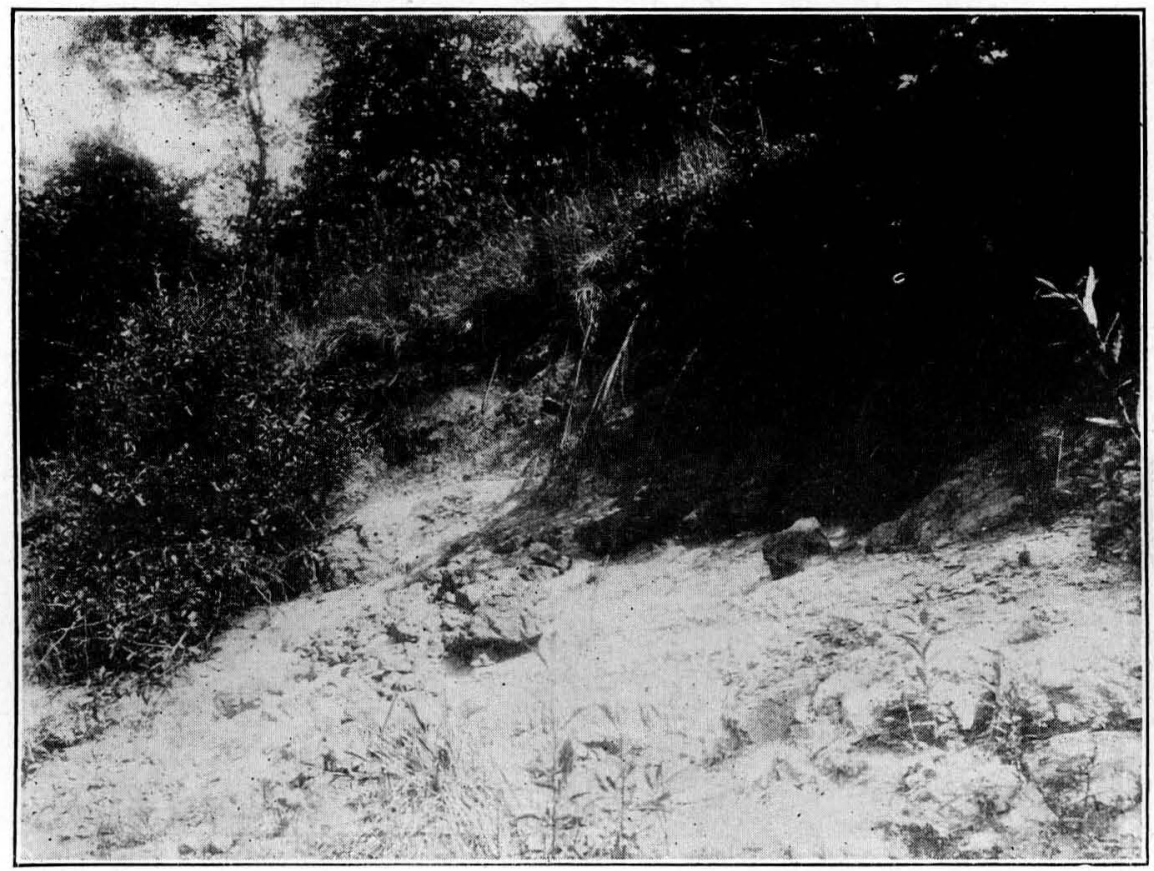

Figure 26. Exposure of Pella beds, Saint Louis stage, overlain by sandstones and shales of the Des Moines stage. South bank of the Skunk river, section 35, Sugar Creek township.

1. Zaphrentis pellaensis Worthen.

2. A Monticuliporoid bryozoan.

3. Schuchertella keokuk Hall or S. crenistriatus Phillips.

4. Productus marginicinctus Hall.

5. Productus ovatus Hall.

6. Pugnax ottumwa White.

7. TerebratuTa turgida Hall.

8. Spirifer keokuk Hall.

9. Athyris subquadrata Hall.

10. Alterisma marionensis White. 
Spirifer keokuk is more common in the upper part of the formation, while Productus ovatus and Pugnax ottumwa are found only lower down in the limestone at the bed of the river.

In the northwest quarter of the southwest quarter of section 36 , Sugar Creek township, in the east bank of the river near the Stillwell bridge, eight feet of rather heavily bedded, compact limestone is exposed. It represents the middle phase of the

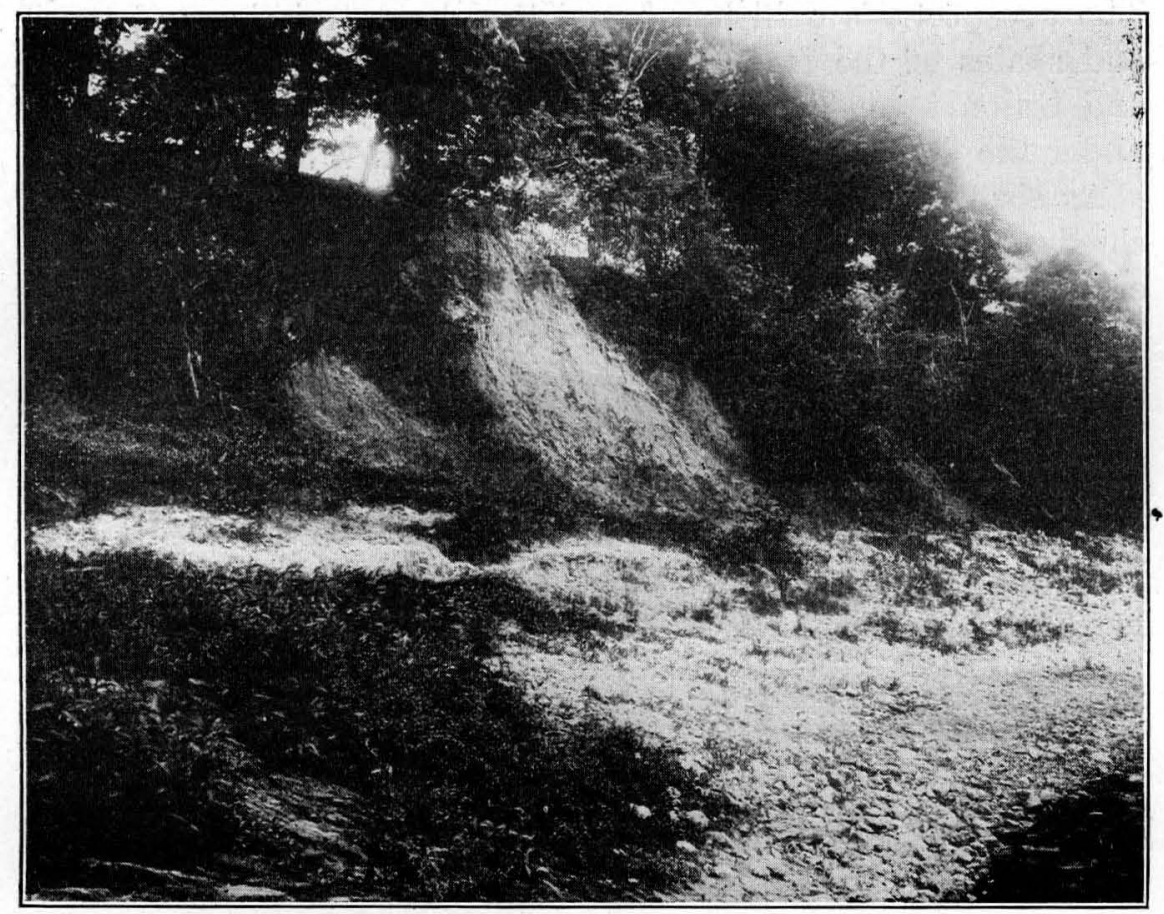

Figure 27. Exposure of Verdi beds, Saint Louis limestone, in left bank of the Skunk river, northwest quarter of section 36, Sugar Creek township.

Saint Louis stage, known from the typical exposure at Verdi in Washington county, as the Verdi beds. No fossils were noticed. Above the limestone exposure the drift is intermingled with fragments of limestone indicating the extension of these beds upward. Elsewhere, as in Washington county, the Verdi beds are characteristically brecciated, and in Keokuk county they alternate with beds of sandstone. The phase represented here is the compact cherty form of the limestone which to the southeast is found associated with sandstone. 


\section{Pennsylvanian Series}

DES MOINES STAGE.

Deposits of the Des Moines stage form the country rock over approximately the southwestern third of the county. They are exposed at several points along the North Skunk river and its tributary, Buck creek, but elsewhere are deeply buried by drift. The prospector's drill has found the characteristic sandstones and shales of the formation at various places in Sugar Creek and Union townships and well makers report similar deposits under the drift in Washington and Jackson townships.

As elsewhere the rocks of this stage in Poweshiek county are chiefly sandstones, shales and coal. There is but little to indicate their thickness except the few outcrops along the North Skunk river, where some thirty feet of Coal Measure sandstones and shales are exposed. They are doubtless comparatively thin everywhere in this county, and grow thinner toward the margin. The outcrop in the south bank of the North Skunk river in Sugar Creek township (northwest quarter of the southwest quarter of section 36) shows the following:

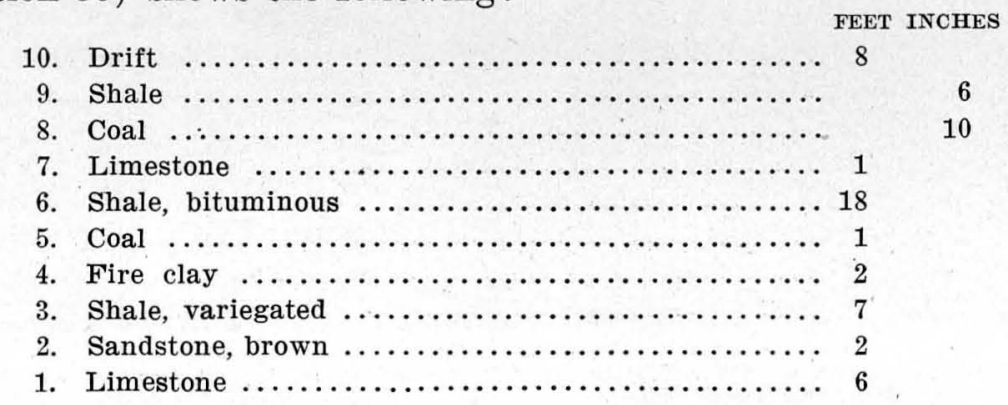

Of this section 1 is Saint Louis and 2 to 9 are Des Moines. This is the site of one of the early mining enterprises of the county.

The Coal Measure strata in southern Iowa were deposited on the eroded surface of the Saint Louis limestones. Preceding the Carboniferous period the interior region, of which Iowa is a part, was a land surface, and in this particular area the Saint Louis limestones formed the country rock. The agencies of erosion had done their work and a very irregular surface with hills, valleys, ridges and streamways was the result. 
The Carboniferous period was ushered in by a widespread depression of the interior of the continent and the encroachment of the sea upon the old eroded Saint Louis surface in such a way as to form shallow estuaries and salt water marshes. The climatic conditions were such as to produce a luxuriant growth of vegetation in these marshes, the accumulated remains of which formed the coal. The shales and sandstones associated with the coal seams represent shore deposits, which under gradual changes of elevation were laid down upon the accumulations of vegetable matter.

Toward the close of the Carboniferous period that part of the interior of the continent in which Iowa is comprised rose high above the sea and became a permanent land surface never again to be submerged beneath the sea. During the extremely long period represented by the closing stage of the Paleozoic, the whole of the Mesozoic, and the earlier part of the Cenozoic, our area was a land surface, subject to the same processes of change that are in operation today. The rocks were disintegrated into soils, while water as rain, snow, ice, surface wash, springs and streams carried on its characteristic work. The progressive changes by which a drainage system establishes itself, matures and passes into old age were repeated again and again during these long periods of time. At first the streamways began to cut valleys and drain the surface. These simple streams developed by working back farther and farther from the sea into the interior. Tributaries were formed and increased in size and number until complex drainage systems were formed. Valleys were widened, ever encroaching upon the inter-stream areas and more, and more completely draining them. Finally the divides disappeared, peneplains were formed, the rivers became sluggish and meandering, the cycle was complete.

The re-elevation of the region would start stream action anew, and the cycle of changes would be repeated. Thus were the upper Paleozoic accumulations gradually disintegrated and carried into the Mesozoic seas. To what extent this process went on the vast length of time involved and the extremely uneven character of the ante-Pleistocene surface bear abundant testimony. 
At various places to the east and southeast of the Des Moines terrane, as far as the Mississippi river, are outliers of this formation. Evidently it originally covered Iowa as far at least as the Mississippi and may have been continuous with the Coal Measures of Illinois. These patches of the Des Moines sandstone escaped the agencies of erosion which carried away every vestige of the formation around them.

\section{QUATERNARY SYSTEM Pleistocene Series}

The deposits of Poweshiek county that are later than the Coal Measure sandstones and shales belong to the Pleistocene and recent epochs of the Cenozoic era. They consist of glacial drift, alluvium and loess. They overlie the indurated rocks to a depth varying from a few inches to several hundred feet.

Nebraskan Stage: There are no surface exposures of till in this county older than the Kansan. The Nebraskan, the oldest known drift sheet in Iowa, is exposed at the surface at comparatively few points in the state. An old soil and forest bed at the top of this sheet and other lines of evidence indicate an interglacial stage, the Aftonian. Well sections in Poweshiek county seem to show this old forest bed and beneath it a bowlder clay which may be Nebraskan. The well on the Holmes farm south of Brooklyn, as reported by Mr. W. W. Shannon is as follows:

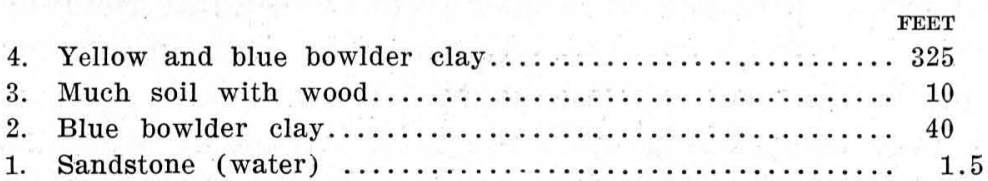

The Jones well (southeast quarter of section 19, township 81, range 14 west) is reported by Mr. Shannon as follows:

4. Yellow and blue bowlder clay ................. 375

3. Forest bed, plenty of ill-smelling water............ 16

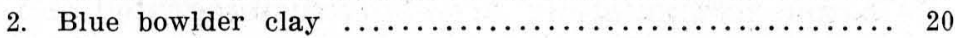

1. Sandstone (water)

In these sections number 1 is Coal Measure sandstone, number 2 Nebraskan (?) drift, number 3 Aftonian (?), number 4 Kansan. 
Kansan Drift: The Kansan till is spread over practically the whole of the county. Generally it has a thickness of several hundred feet. Its characteristics are in general the same here as elsewhere in Iowa. It is typically a stiff blue clay containing rock fragments or bowlders of very great variety. Under oxidation and weathering it changes in color to yellow or brown, or where there is considerable iron, to a red color. It presents various phases and conditions. It often contains inclusions of sand and gravel which form important aquifers. In general it is unstratified but in places gives distinct evidence of the sorting effect of water.

The Kansan drift is exposed generally along the roadways and in railroad cuts. Excellent exposures are found in the cuts of the Iowa Central railroad north of Searsboro, where the relations of the loess to the drift may be seen. Between the Kansan drift and the capping of loess is found a line of bowlders, showing that the Kansan surface was eroded and the finer materials removed by wind and water before the loess was deposited.

Loess: This fine dust-like, drab colored material is laid down quite generally in Poweshiek county as a covering to the Kansan drift. It varies in thickness from nothing to twenty-five or more feet. It is thicker along the streams and thins out on the divides. The peculiar lime concretions known as loess-Kindehen are abundant in places.

\section{Recent Series}

ALLUVIUM.

This is of recent origin and is found along the principal streams. As the valleys have been widened, the materials eroded from the uplands and valley slopes have been distributed over the bottoms to form alluvial flood plains.

\section{SOILS}

Soils are made up of the products of rock decay mingled with more or less vegetable matter or humus. The soils of Poweshiek county are largely derived from the Kansan drift, which 
itself is rock debris from widely different sources, ground up and worked over in various ways and distributed by the great ice mill and later by aqueous agencies.

The productiveness of any soil depends not only upon its composition, but also upon its physical properties. The drift by its origin forms an ideal soil basis. It contains in abundance a very great variety of rock ingredients finely comminuted and commingled. When the final retreat of the last ice sheet took place, forms of plant life gradually obtained possession of the vast waste of comparatively level, undrained land, and vegetation in ever-increasing variety and luxuriance began to clothe the surface. The annual growth of vegetable tissues, whether in lake, marsh or bog, or on well drained surface, was left in a partially decayed condition to accumulate from year to year. These accumulations became peat or the dark carbonaceous mud of lakes, or the humus of drier lands. The ever changing conditions of erosion redistributed these accumulations, mingling with them new elements eroded from the drift and the result was the rich soils so characteristic of the Kansan drift plain of which Poweshiek county forms a part.

Drift Soils: The upland soils of Poweshiek county have generally the Kansan clays as a basis. In places where erosion has been excessive, the bowlders lie at the surface and the larger ones must be removed from the fields by hand. Generally, however, there is a sufficient accumulation of humus and material of æolian origin at the surface so that the plow does not come in contact with the bowlders.

All that is necessary to perpetuate these upland drift soils in all their productiveness is to return sufficient humus to them to compensate for that which is removed by cropping, and to utilize the clovers and other leguminous plants for their wellknown power of storing in the soil nitrogen compounds in available form for plant food. Rich as these soils were when first broken up as virgin prairie, there is no reason why, by proper tillage and management, they may not be made more and more productive.

Loess Soils: This æolian deposit varies considerably in chemical composition in its different phases and in different localities, but it is always rich in the elements of plant food. In its best 
condition, it is porous and very productive. It forms the soil on the uplands, especially along the streams. It is characteristic of the rougher, more broken parts of the county. For this reason it is often subject to excessive erosion and the problem is to keep it supplied with sufficient humus. It is fortunately well adapted to the growth of clover, and by the proper rotation of this with other crops, the fertility and proper physical condition of this valuable soil may be maintained. The forested parts of the country were originally confined to the loess-covered hilly areas along the streams and there seems a peculiar adaptation of this soil to forest growth and for this reason to the growing of fruit trees. Some of the finest orchards in the county are found where the loess is deepest.

In many of the more hilly parts where the original timber has been removed, the reforesting of the loess hills would give a larger future reward than any other use that could be made of them. On these hills, erosion is so excessive as to make farming unprofitable and their roughness makes it extremely laborious. If they were planted to forest trees or allowed to become forest covered in nature's way, under proper management they would soon become very profitable. Every encouragement should be given to the conservation of the woodlands that remain, and to the reforestation of areas so subject to erosion as to make their value for tillage doubtful.

Alluvial Soils: These deposits are chiefly in the flood plains of the streams. They consist of the material that has been carried down from the uplands and spread over the valley floors. They are generally rich, warm, well underdrained and highly productive.

\section{ECONOMIC PRODUCTS}

\section{Coal}

The eastern margin of the coal area crosses this county, approximately the southwestern third of it being covered with Coal Measure deposits. It is possible that outliers of the same formation may exist beyond this border within the limits of the county. Notwithstanding the fact that Poweshiek is thus in pari within the coal area, it cannot be considered a coal producing county. In fact, almost no coal has been mined within its limits for many years. 
Along Buck creek in Union township, some coal was formerly mined, but the seam, which was a foot in thickness at the outcrop, thinned rapidly and was soon exhausted.

On the south side of the North Skunk river (northwest quarter of the southwest quarter of section 36, Sugar Creek township) is the old Petit mine. This mine was at one time fairly productive and supplied the local demand. The vein was sixteen inches in thickness. No coal has been taken from this drift for a number of years. Recently an unsuccessful attempt has been made to locate a second seam several rods up the draw from the Petit drift. It is very doubtful if such a second seam exists at this point.

Prospecting has been carried on west and south of Searsboro where thin seams of coal were found, but not promising enough to warrant further effort. A more thorough exploiting of the region with the drill which is sure to be made in the future may reveal profitable seams of coal within the county.

3. Shale, bituminous, (exposed).

2. Coal.

1. Fire +clay (exposed).

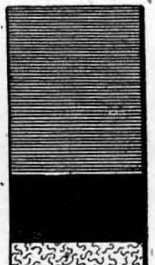

FEET INCHES

Figure 28. Coal at Smith and Barrowman mine, Searsboro.

\section{Clay Products}

An inexhaustible supply of material for brick and tile exists everywhere within the county. Clays derived from the Kansan drift are common on the lowlands and are of fine quality. Certain phases of the loess afford an excellent material for certain grades of brick and tile. Large supplies of shale may be had at the site of the old Petit mine on the North Skunk river, and along Buck creek.

The Grinnell Brick and Tile Company of Grinnell has a well equipped plant for the manufacture of brick and tile. The loess used here is of the blue phase and more than usually plastic. It mäks an excellent product. 
Mr. B. J. Broadston, of Montezuma, manufactures brick and tile of good quality. He uses the soft mud method. His plant is equipped with a "Bensing" cutting machine and has a capacity of 30,000 brick per day. He has four down-draft kilns.

Mr. Peter Meyer has a small plant for the manufacture of brick and tile near Stillwell in Sugar Creek township.

\section{Water Supply}

Throughout the county the water supply is largely from wells in the drift, usually a local sand or gravel bed being the immediate aquifer. Several wells reported from memory by Mr. W. W. Shannon have their supply in the Des Moines sandstone, and a few others in the Saint Louis limestone.

Three deep wells have been sunk at Grinnell from which the city is supplied. The depth of these wells is a little over 2,000 feet. Professor Norton* is authority for the facts here presented, his study being based on well No. 1 . The depth is 2,003 feet, the head of water above tide 798 feet and the elevation of the curb 1,028 feet above tide.

The diameters of the bore are as follows: Ten inches to 208 feet, six inches to 408 feet, five inches to 1,185 feet and four inches to 2,003 feet. Ten-inch casing occupies the ten-inch bore, 450 feet of five-inch casing is located at a depth of from 408 feet to 958 feet, covering the shales of the Mississippian and Devonian, and forty feet of four-inch casing from 1,145 feet to 1,185 feet from the surface.

Water was first found at 212 feet, at the top of the Saint Louis limestone, strongly mineral, almost yellow in color, and rising to within ninety feet of the surface. The inflow of this water could not be checked for a long time, but before the well was completed it was entirely shut off. The second water was found at 1,530 feet from the surface in the Trenton. A third flow was encountered in the Saint Peter at 1,700 feet. This was a strong vein, and "as the drill penetrated the sandstone a roaring noise was heard, and the drillings were washed away by the strong current of water." The water in the tube, which had remained at about 100 feet below the surface, immediately sunk, and this was no doubt the cause of the roaring noise reported. After some time the water returned to nearly the same level. The head of the Saint Peter and Trenton water is in this region ap-

*Artesian wells of Iowa, Vol. VI, pp. 287-292. Iowa Geol. Survey. 
parently about 928 feet, but this high level is probably due to a filling of the well with the higher waters faster than it could be drawn off through the lower outlet. More or less water was found all the way from 1,700 feet to 2,003 feet, and on completion of the well the head was found to be 230 feet from the surface.

\section{ANALYSES}

The quality of the water at different depths was carefully tested during the progress of the boring. Four separate analyses were made. Number 1 is of the combined water of the first, the second and third flows. Number 2 is of the second and third flows, the first being shut off. These are both by Professor L. W. Andrews, of Iowa City, and were made when the well had reached a depth of 1,770 feet, when water was first pumped from the well. Number 3 and number 4, by Mr. Luther Verbeck, of Grinnell, represent the constitution of the combined waters of all flows, except the first, to their respective depths of 1,940 feet and 2,003 feet.

\begin{tabular}{|c|c|c|c|c|}
\hline & 01 & 2 & & \\
\hline alcium carbonate & & & 5.89 & \\
\hline alcium sulphate & 45.25 & 41.25 & 42.55 & 41.10 \\
\hline Magnesium sulphate & 41.60 & 41.00 & 24.60 & 30.00 \\
\hline um sulphate $\ldots$ & 24.75 & 23.35 & 24.60 & 30.00 \\
\hline Sodium chloride ...... & 0. & 0.05 & 0.50 & 0.8 \\
\hline ion $\ldots \ldots \ldots \ldots \ldots \ldots \ldots \ldots \ldots \ldots$ & $\ldots$ & $\ldots$ & 0.17 & .. \\
\hline $\mathrm{a}$ & $\ldots$ & $\ldots$ & 0.65 & \\
\hline$\ldots$ & $\ldots$ & $\ldots$ & $\ldots$ & 0.7 \\
\hline otal dissolved solids.. & 121.35 & 115.25 & $\ldots$ & 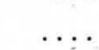 \\
\hline Total suspended & 14.55 & 2.85 & $\ldots$ & \\
\hline otal solids $\ldots$. & 135.90 & 118.10 & 112.30 & 120.7 \\
\hline Iardness .. & $78^{\circ}$ & $74.1^{\circ}$ & $41^{\circ}$ & $44^{\circ}$ \\
\hline
\end{tabular}

The similarity of the first two analyses is certainly surprising, if the strong mineral water present in the water of number 1 were really excluded from the water of number 2 ; and the same may be said of the uniformity in the amount of calcium sulphate in all the waters and of sodium sulphate in the first three.

The water is said to be universally liked and very generally used. Physicians report that there has been a marked decrease in zymotic diseases since its introduction, and that it seems to be beneficial in cases of chronic rheumatism. It is at first laxative and diuretic to those unaccustomed to its use, but the di- 
uretic effect ceases and the laxative effect is changed to constipation. Patients with chronic diarrhoea ean not take it at all. It is one of the strongest selenitic waters in the state.

\section{RECORD OF STRATA.}

THICKNESS DEPTH

41. Soil, loess and drift............... $212 \quad 212$

40. Limestone, rather soft, buff, in chips mixed with sand and small pebbles of northern

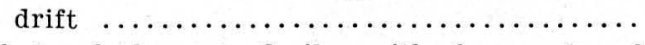

39. Shale, dark gray, fissile, with fragments of impure chert, in light drab argillo-calcareous powder ....................

38. Limestone, cherty, arenaceous, argillaceous; after washing is seen to contain many minute crystals of selenite.............

37. Limestone, gray, as fine sand in argillo-calcare-

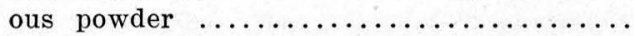

36. Limestone, cherty, and shale, as chips in argillocalcareous powder ................ 125

35. Shale and limestone, soft, fissile, dark drab; in powder with a few minute fragments of limestone and considerable chert........... 35

34. Shale, blue, calcareous, in powder concreted into readily friable masses containing microscopic particles of quartz..............

33. Shale, hard, green-gray, with compact, light yellow, calcareous, siliceous fragments; siliceous in the form of angular grains of transparent quartz, mostly from .054 to $.09 \mathrm{~mm}$. in size, but many much smaller..........

32. Shale, fine-grained, calcareous, greenish.....

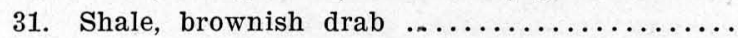

30. Shale, light blue-gray, somewhat calcareous,

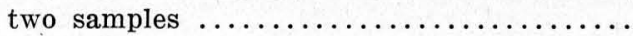

29. Shale, as No. $31 \ldots \ldots \ldots \ldots \ldots \ldots \ldots \ldots \ldots$

281/2 Limestone, fine-grained (report A. J. Jones) at

28. Shale, light blue-gray, seleniferous, calcareous, with a few particles of limestone.........

27. Shale, light drab and bluish, somewhat calcareous, with a little finely divided quartzose residue after washing, five samples...... 400

26. Limestone, light yellow-gray, granular, subcrystalline, briskly effervescent in cold dilute $\mathrm{HCl}$, with much shale............. 10

25. Shale and limestone, in light blue-gray argillaceous powder containing a few fragments of limestone 
THICKNESS DEPTH

24. Shale, light blue and green-gray, somewhat calcareous, seven samples, last at $900 . \ldots$.

23. Limestone, magnesian, medium dark gray,

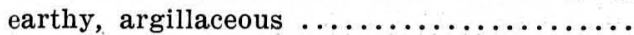

22. Limestone, magnesian, or dolomite, with considerable hard, finely arenaceous, greenish

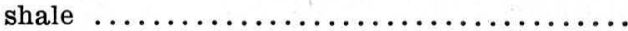

21. Shale, light gray, argillo-calcareous.........

20. Limestone, highly cherty ..............

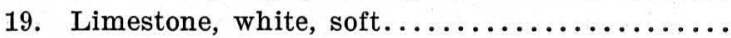

1,065

18. Limestone, highly cherty, two samples.......

17. Limestone, cherty $\ldots \ldots \ldots \ldots \ldots \ldots \ldots$

16. Dolomite or magnesian limestone, light buff,

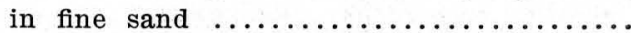

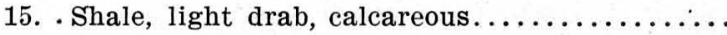

14. Shale, light brown, pyritiferous, two samples,

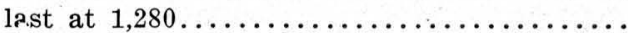

13. Magnesian limestone or dolomite, buff; residue cherty and microscopically arenaceous......

12. Shale, brown, darker than No. $14 \ldots \ldots \ldots \ldots$

11. Magnesian limestone or dolomite, ferruginous, in dark buff powder; residuary quartzose particles .018 to $.18 \mathrm{~mm}$. in diameter, four

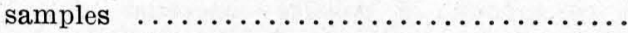

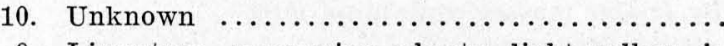

9. Limestone, magnesian, cherty, light yellow, in

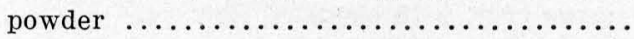

8. Limestone, light gray, fossiliferous, in flaky

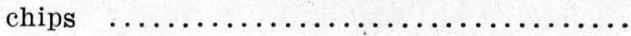

7. Shale, green, non-calcareous, "fossiliferous"..

6. Limestone, magnesian, in buff powder........

5. Sandstone, calciferous, quartzose particles from .018 to $.18 \mathrm{~mm}$. in diameter; particles of white dolomite mingled with the quartz in

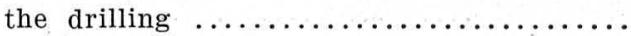

4. Sandstone, white, grains rounded and smooth, usual size about $.55 \mathrm{~mm}$., maximum seen .92

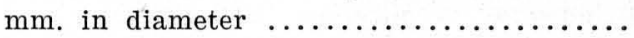

3. Sandstone, light reddish buff, fine grains, mostly broken, many stained with film of ferric oxide, size .18 to $.28 \mathrm{~mm}$. in diameter

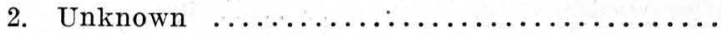

1. Sandstone, highly calciferous, or limestone, arenaceous; sand grains angular with some rounded and up to $1 \mathrm{~mm}$. in diameter, matrix

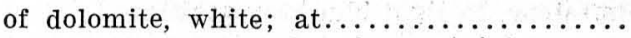




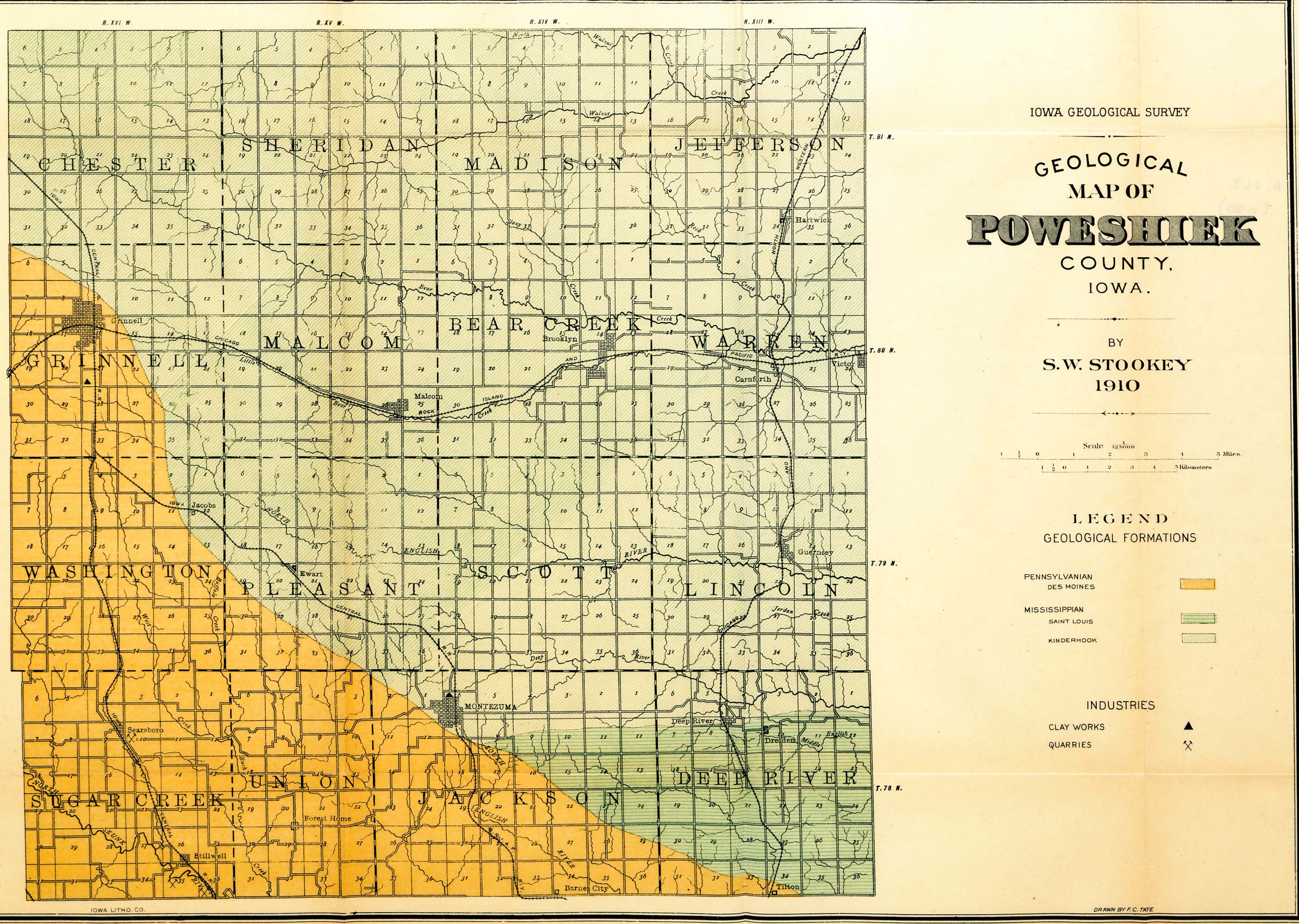




\section{ACKNOWLEDGMENTS}

I found the most ready coöperation on the part of a large number of citizens of Poweshiek county in gathering the data for this report. The officials of the Grinnell municipality furnished copies of the deep well records. Mr. Rayburn of Grinnell facilitated the work in various ways. Mr. W. W. Shannon and other well-makers freely furnished information at their command. Professor Hendrixson gave valuable suggestions. Especially is grateful acknowledgment due the Director of the Survey for his help in the field work, for the photographs illustrating the report and for the identification of the species of the Saint Louis fauna. 
